\title{
ESTIMATION OF TEMPERATURE CO-EFFICIENT OF WHEAT FOR ADJUSTING PROPER SOWING TIME
}

\author{
A.A. Begum*', M.A.K. Mian' ${ }^{1}$, J. Rahman ${ }^{2}$, M.M. Khanum ${ }^{3}$, M.Z. Ali ${ }^{1}$ and R.R.Saha ${ }^{4}$ \\ ${ }^{1}$ Agronomy Division, BARI, Gazipur, ${ }^{2}$ RARS, Jamalpur, ${ }^{3}$ ARS, Rajbari, Dinajpur and \\ ${ }^{4}$ Oilseed Research Centre, BARI, Gazipur \\ *Corresponding E-mail: luckyshamol6869@gmail.com
}

(Received: 30 September, 2020, Accepted: 24 November, 2020)

Keywords: Temperature co-efficient, sowing time, wheat, GDD, LAI, DM, grain growth, yield

\begin{abstract}
The field experiment was conducted at Agronomy research field, Joydebpur, Gazipur (Latitude: 23.999941, Longitude: 90.420273), RARS, Jamalpur (Latitude: 24.923025, Longitude: 89.950111) and ARS, Rajbari, Dinajpur (Latitude: 25.63544, Longitude: 88.65144) of BARI during rabi of 2018 - 2019 to observe the growth behavior and yield of wheat as influenced by prevailing air temperature based on sowing time. There were five sowing dates viz., $D_{1}=10$ November, $D_{2}=20$ November, $D_{3}=30$ November, $D_{4}=10$ December and $\mathrm{D}_{5}=20$ December. Sowing date showed great influence on TDM production, LAI, physiological maturity, yield and yield components of wheat. 30 November sowing produced the maximum TDM and LAI followed by 20 November sowing. These parameters finally contributed to higher grain yield than earlier and later sowing date. The crop sown on 30 November took the longest period (105, 106 and 109 days, respectively) to attain the physiological maturity with the highest GDD (1639, 1638 and 1640 respectively) and 20 December sown crop took the shortest period (95, 96 and 98 days respectively) to attain the physiological maturity with the lowest GDD (1530, 1528 and 1525 at Joydebpur, Jamalpur and Rajbari, respectively).It was also found that 30 November sown crop produced the higher grain yield $\left(4.90 \mathrm{t} \mathrm{ha}^{-1}, 4.99 \mathrm{t} \mathrm{ha}^{-1}\right.$ and $5.03 \mathrm{t}$ $\mathrm{ha}^{-1}$ at Joydebpur, Jamalpur and Rajbari, respectively). The results revealed that 20-30 November sowing produced higher grain yield might be due to favourable air temperature for growth and development. Late sowing after November 30 produced lower grain yield due to high temperature prevailed at the later growth stage (March) of wheat at Joydebpur, Jamalpur and Rajbari region. The temperature co-efficient of wheat was estimated at $2.41 \mathrm{t} \mathrm{ha}^{-1}\left(1.95-2.89 \mathrm{t} \mathrm{ha}^{-1}\right)$ indicated grain yield reduced $2.41 \mathrm{t} \mathrm{ha}^{-1}$ per $1^{\circ} \mathrm{C}$ increased of air temperature and effect of temperature on the grain yield of wheat was estimated at $81-84 \%$.
\end{abstract}

\section{Introduction}

Wheat (Triticum aestivum L.) is the most important crop in the world that excels all other cereals both in area and production (Costa et al., 2013). It is also one of the most nutritious cereals that contributed to human diet putting it in the first rank to feed the world. In Bangladesh, it is the second major cereal crop after rice as human food. While wheat is grown over a wide range of environments, it is common in the major wheat-producing countries for grain filling to occur when soil moisture is declining and temperature is increasing (Asseng et al., 2010). Wheat is primarily grown across the exceptionally diverse range of environments. The optimum temperature for anthesis and grain filling of wheat ranges from 12 to $22{ }^{\circ} \mathrm{C}$. The optimum temperature required for wheat growing period is $20^{\circ}$ to $25^{\circ} \mathrm{C}$ and the maximum temperature is $35^{\circ} \mathrm{C}$. If temperature is more than $30{ }^{\circ} \mathrm{C}$ at the time of maturity, it leads to force maturity which is responsible for yield loss (Uddin et al., 2015). Post-anthesis heat stress in wheat induces several physiological functions which eventually produce in lesser grain weight as a 
result of reduced grain filling period and starch synthesis duration or the combined effect of both. The Organization for Economic Co-operation and Development (OECD) (2003) focused on rises in temperature of $1.4{ }^{\circ} \mathrm{C}$ by 2050 and $2.4{ }^{\circ} \mathrm{C}$ by 2100 in Bangladesh. Islam (2009) estimated that temperature increases over the past 100 years for all over Bangladesh at $0.62{ }^{\circ} \mathrm{C}$ (maximum) and 1.54 ${ }^{\circ} \mathrm{C}$ (minimum) occurred in February from 34 meteorological Climate sites in Bangladesh. Those predictions of climate change and prediction of the effect of global warming is becoming the reality in Bangladesh. Thus the crop is being exposed to biotic and abiotic stresses due to adverse effect of climatic change.

The seasonal and yearly variations in temperatures, humidity and rainfall distribution caused fluctuation in yield and production of wheat in last couples of years in Bangladesh. Experimentations have been done to improve wheat yield through manipulating sowing time (Hossain et al., 2009). The sowing date of wheat is considered as most important factor limiting the wheat yield and it is reported that wheat yield decreased at the rate of $1.3 \%$ per day delay sowing after 30 November under the short spell of winter in Bangladesh (Ahmed et al., 1998). Since, wheat is grown in winter season and winter is becoming warmer and shorter due to climate change, the dry matter production, grain growth and yield of wheat crop may be affected by higher temperature. Sowing time of wheat may be adjusted to exploit the full yield potentiality exploring the agro-environmental benefit. Therefore, the experiment was conducted to observe the growth behavior and yield of wheat as influenced by prevailing air temperature as well as other weather elements based on sowing time.

\section{Materials and Methods}

The experiment was conducted at the research field, Joydebpur, Gazipur (Latitude: 23.999941, Longitude: 90.420273), RARS, Jamalpur (Latitude: 24.923025, Longitude: 89.950111) and ARS, Rajbari, Dinajpur (Latitude: 25.63544, Longitude: 88.65144) during rabi of 2018 - 2019. The soil was silty clay in texture at Joydebpur (AEZ-28), silty loam at Jamalpur (AEZ-9) and sandy loam at Rajbari (AEZ-3). The treatments were five sowing date: $D_{1}=10$ November, $D_{2}=20$ November, $D_{3}=30$ November, $\mathrm{D}_{4}=10$ December and $\mathrm{D}_{5}=20$ December. The experiment was laid out in a RCB design with three replications and the unit plot size was $5 \mathrm{~m} \times 4 \mathrm{~m}$ in all locations. Wheat seeds were sown as per treatment in line with maintaining $20 \mathrm{~cm}$ row to row spacing. Fertilizers were applied @ 120-30-90-153-1 kg ha ${ }^{-1}$ of N-P-K-S-Zn-B, respectively (BARC, 2012), in the form of urea, triple super phosphate, muriate of potash, gypsum, zinc sulphate and boric acid. Two third of urea and full doses of other fertilizers were applied at the time of final land preparation. The remaining one third of urea was top dressed at CRI stage followed by irrigation in all locations. Data on growth parameters like leaf area and dry matter accumulation were measured at different dates with 15 days interval at Joydebpur location. To record dry matter weight and leaf area, one linear meter was sampled at 15, 30, 45, 60, 75 DAS and at harvest. Different plant parts of the collected samples were separated and then oven dried at $80^{\circ} \mathrm{C}$ for 72 hours. Leaf area was measured by an automatic leaf area meter (L13100 c, L1COR, USA). Daily air temperatures were recorded for computing the growing degree days (GDD). The GDD was calculated using the following formula:

$$
\mathrm{GDD}=\sum \frac{\mathrm{Tmax}+\mathrm{Tmin}}{2}-\mathrm{T}_{\text {base }}
$$

Where, $\mathrm{T}_{\max }$ and $\mathrm{T}_{\min }$ are daily maximum and minimum air temperatures, respectively. $\mathrm{T}_{\text {base }}$ indicated base temperature of wheat $\left(5^{\circ} \mathrm{C}\right)$. The GDD can be summed over days to indicate the amount of heat for growth that the crop has received over the period of the growing season (Kumar et al., 2008).

For estimation of physiological maturity and grain growth study, five spikes were harvested from each plot after anthesis starting from 5 days after anthesis at four days interval. It was continued up to 32 days after anthesis (DAA). The harvested spikes were oven dried at $70^{\circ} \mathrm{C}$ for 72 hours. Twenty grains of each spike were separated from the middle of each spike and then weight was taken. The crop was harvested at physiological maturity. The 10 November, 20 November, 30 November, 10 December and 
20 December sowing crops were harvested on 3 March, 6 March, 13 March, 19 March and 28 March, respectively. Yield contributing characters were recorded from one linear meter at the time of harvest. Yield data were recorded by harvesting ten square meter area excluding border. Data was analyzed statistically following MSTAT-C software package Gomez and Gomez (1984) and means were compared using LSD test at $5 \%$ level of significance.

\section{Results and Discussion}

\section{Effect of sowing date on leaf area index}

The LAI was influenced by different sowing dates over time (Fig. 1). The LAI increased sharply and reached the peak at 60 DAS when the crop sown on 10, 20 and 30 November. On the other hand, LAI increased sharply and reached the peak at 45 DAS when sown on 10 and 20 December then declined up to harvest. The reduction of LAI after the peak might be due to leaf senescence. Among the sowing dates, 30 November sowing showed the highest LAI (4.0) at 60 DAS and it was higher throughout the growing period except at 45 DAS. This has happened due to optimum sowing time (30 November sowing) produced the highest LAI across the different sowing dates. The lower LAI was observed on 20 December sowing at all over growing period except 45 DAS. Because leaf area of the crop sown on 10, 20 and 30 November increased up to 60 DAS due to getting longer vegetative phase and leaf area of the crop sown on 10, 20 December increased up to 45 DAS due to getting shorter vegetative phase.

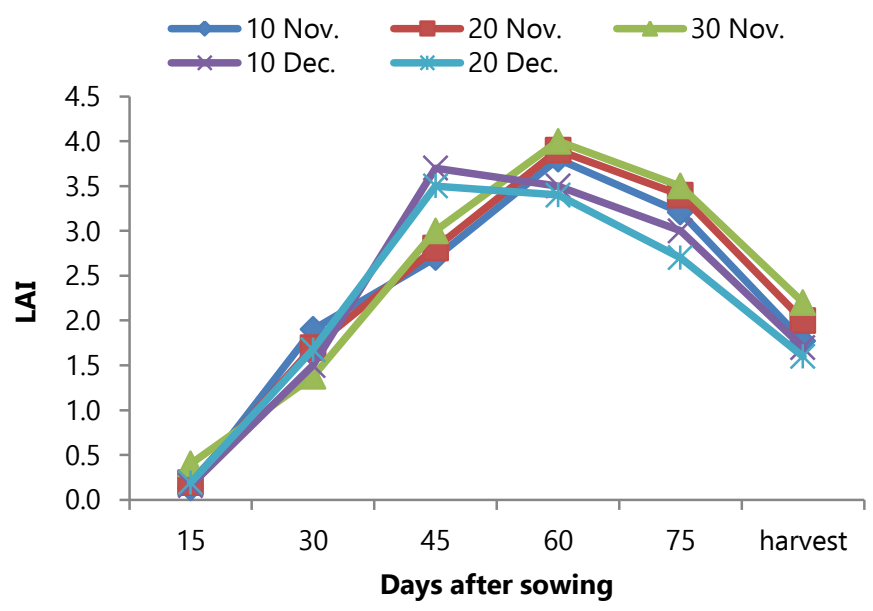

Fig. 1. LAI of wheat at different DAS as influenced by sowing dates

\section{Effect of sowing date on TDM production}

The pattern of TDM accumulation in wheat over time was influenced by different sowing dates (Fig. 2). The TDM of wheat increased slowly up to 45 DAS when crop sown on 10, 20 and 30 November. After 45 DAS dry matter accumulation rate increased rapidly up to harvest. In December sowing, TDM production increased slowly up to 30 DAS. After 30 DAS dry matter accumulation rate increased rapidly up to 75 DAS and then increased slowly till the harvest. The highest TDM accumulation $\mathrm{m}^{-2}$ was obtained from 30 November sowing at harvest followed by 20 November sowing and it was higher than other sowing throughout the growing period. The crop sown on 30 November got longer duration might be due to favorable temperature for growth and development as compared to other sowing dates and produced the maximum TDM. The results are in agreement with the findings of Ahmad et al. (2005) and Kamrozzaman et al. (2016) who stated that sowing dates had significant different on dry matter production due to variation of temperature. The lowest TDM was observed in 20 December sowing at all over the growing period. 


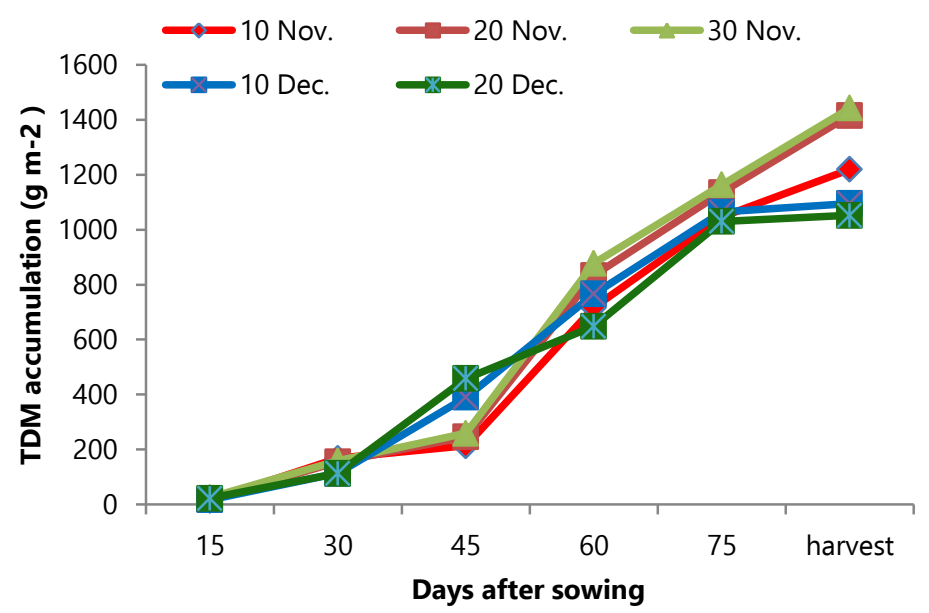

Fig. 2. TDM accumulation of wheat at different days after sowing as influenced by sowing dates

\section{Effect of sowing date on dry matter partitioning}

Pattern of DM distribution in different parts of wheat crop in response to planting dates have shown in Fig. 3. Irrespective of treatments, the difference in dry weight of leaf, stem and spike of wheat was minimum at early growth stages and widened with the advancement of growth. Sowing dates had pronounced effect on DM distribution of wheat over the growth stages. Pattern of DM distribution of wheat was similar in all the sowing dates such that allocation of assimilates to leaves and stems increased to a peak and then decreased with concomitant increase in allocation to reproductive organ (spike). Irrespective of sowing dates, dry matter distribution to leaf of wheat peaked at 60 DAS when sown on 10, 20 and 30 November and peaked at 45 DAS when sown on 10 and 20 December. On the other hand, stem dry matter distribution of wheat peaked at 75 DAS at all sowing dates. The highest leaf and stem dry matter was produced by 30 November sowing and the lowest leaf and stem dry matter was produced by 20 December sowing at all over the growing period. The reduction in dry matter of vegetative parts (leaf + stem) after peak might be due to remobilization of stored assimilates into the grain of wheat. The highest spike dry matter was produced by 30 November sowing and the lowest spike dry matter was produced by 20 December sowing. It might be due to maximum duration (physiological maturity) was recorded in 30 November sowing prevailing optimum temperature in vegetative and reproductive phase. On the other hand, early sown crop got shorter vegetative phase which accumulated lower DM and delayed sown crop got longer vegetative phase which accumulated higher DM along with profuse tillering and shorter reproductive phase due to higher temperature prevailed in later stage. 


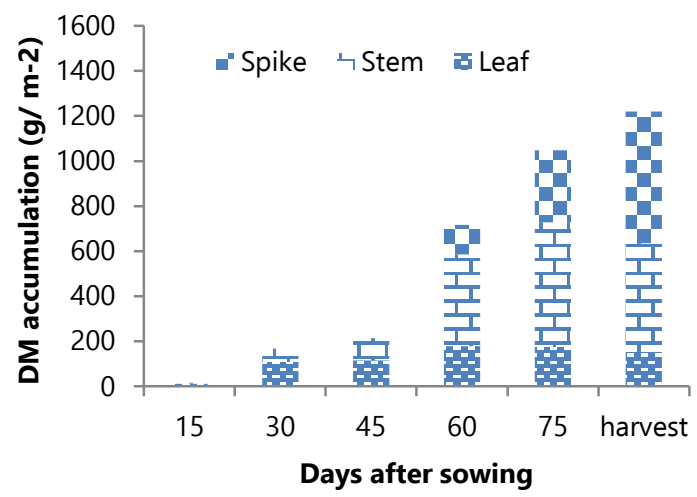

a.10 November

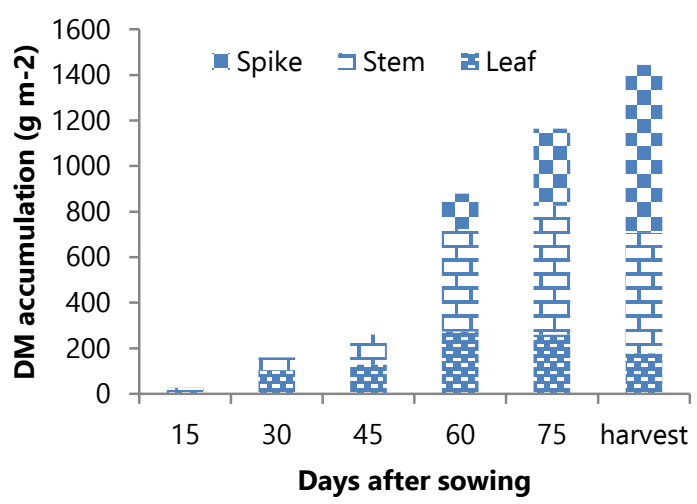

c. 30 Novemver

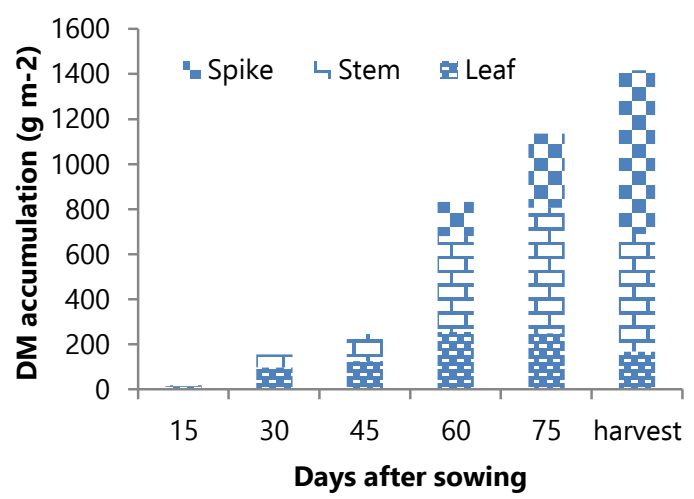

b. 20 November

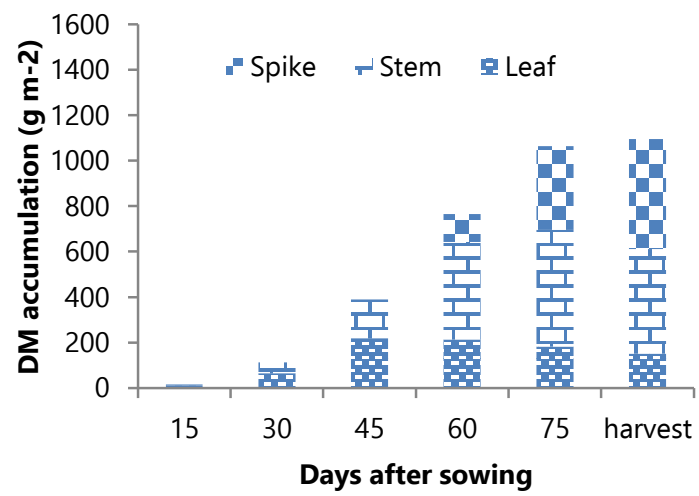

d.10 December

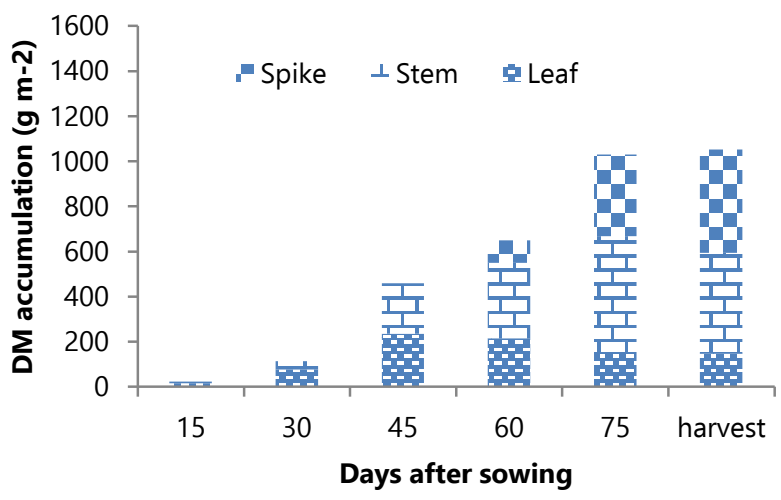

e. 20 December

Fig. 3. Dry matter distribution pattern of wheat as affected by sowing date at Joydebpur

Dry matter distribution pattern of wheat at harvest in response to sowing dates at Joydebpur have shown in Fig. 4.Sowing dates had pronounced effect on DM distribution at harvest of wheat. The highest leaf, stem and spike dry matter was produced by 30 November sowing followed by 20 November sowing. The lowest leaf, stem and spike dry matter was produced by 20 December sowing followed by 10 December sowing. The crop sown on 30 November got longer duration due to 
favourable temperature for growth and development as compared to other sowing dates (Table 3) and produced the maximum TDM (leaf dry matter $=178 \mathrm{~g} \mathrm{~m}^{-2}$, stem dry matter $=528 \mathrm{~g} \mathrm{~m}^{-2}$ and spike dry matter $=736 \mathrm{~g} \mathrm{~m}^{-2}$ ) whereas, 20 December sowing produced the minimum TDM (leaf dry matter $=149 \mathrm{~g} / \mathrm{m}^{2}$, stem dry matter $=444 \mathrm{~g} \mathrm{~m}^{-2}$ and spike dry matter $=459 \mathrm{~g} \mathrm{~m}^{-2}$ ). Thirty November sowing produced $51 \%$ spike dry matter, $37 \%$ stem dry matter and $12 \%$ leaf dry matter of TDM which was $60 \%, 19 \%$ and $19 \%$ higher than those of 20 December sowing (Fig.4).

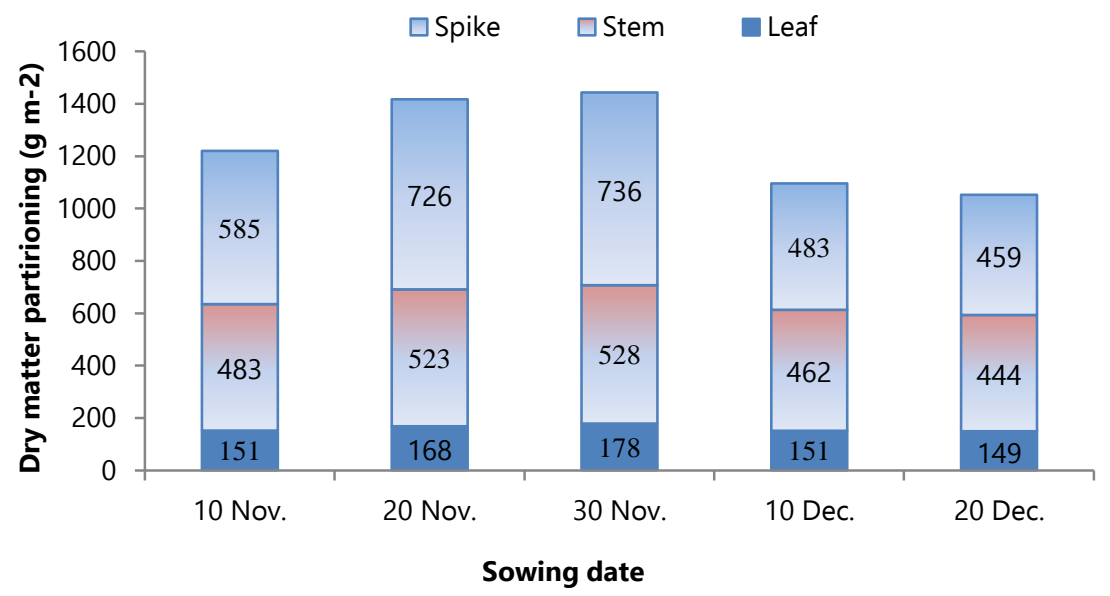

Fig.4. Dry matter distribution pattern of wheat at harvest as affected by sowing date at Joydebpur

\section{Effect of sowing date on grain growth}

Effect of sowing date on grain growth of wheat at Joydebpur has been presented in Fig. 4. Among the different sowing dates, 30 November sowing exhibited higher grain growth in all over the grain filling period. It might be due to prevailing optimum air temperature on 30 November sowing. The crop sown on 20 November to 30 November exhibited higher trend of grain growth as compared to earlier and later sowing (10 November, 10 December and 20 December sowing).Grain growth reached peak at 30 days after anthesis (DAA) when the crop sown on 30 November. The maximum grain weight (52.0 $\mathrm{mg}$ /grain) was observed at 30 DAA when crop sown on 30 November sowing followed by 20 November sowing at 32 DAA. Higher grain growth duration was observed at 10 November sowing but did not produce the maximum grain weight. It might be due to longer vegetative phase ( 75 days) gained maximum dry matter with lower temperature in 30 November sowing which produced the maximum grain weight of wheat. The crop sown on 10 November took the maximum grain growth duration (33 days) but shorter vegetative phase (69 days) with higher air temperature gained comparatively lower dry matter which failed to produce higher grain weight. The lowest grain weight $(40.0 \mathrm{mg} / \mathrm{grain})$ was observed at 21 DAA on 20 December sowing. It indicated that grain weight reduced in late sown condition due to higher air temperature prevailed at later growth stage (March) shortening the growth period of wheat. Similar results were also have been reported by Mian et al. (2016) and Khan and Aziz (2015). They reported that grain growth was maximum in 30 November sowing followed by 15 November sowing while the lowest in 30 December sowing. 


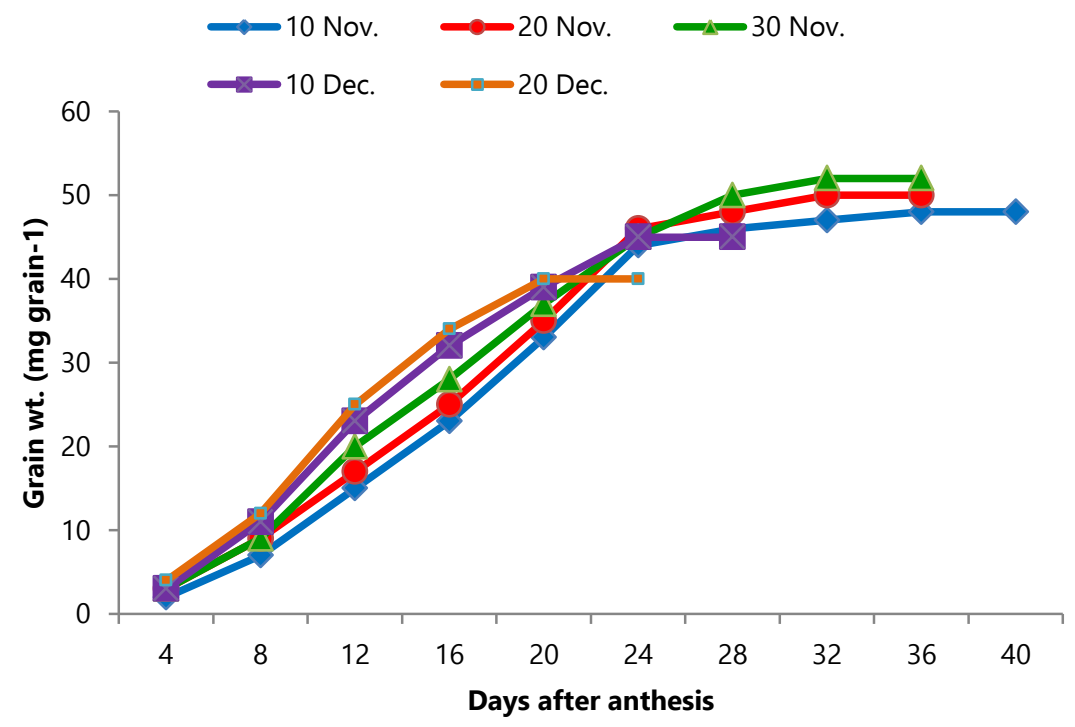

Fig. 4. Grain growth of wheat as influenced by sowing dates at Joydebpur location

\section{Effect of sowing date on physiological duration, mean air temperature and GDD}

Duration, mean air temperature and growing degree day (GDD) for anthesis and physiological maturity of wheat as affected by sowing date have been presented in Table 1. Temperature is an important factor which influences duration of different growth stage of wheat. In Joydebpur, the shortest vegetative phase (69 days) with the lowest GDD (1074) was observed in 10 November sowing due to prevailing higher mean temperature $\left(20.6^{\circ} \mathrm{C}\right)$ and the longest vegetative phase $(75$ days) with higher GDD (1115) was observed in 30 November sowing due to prevailing lower mean air temperature $\left(19.9^{\circ} \mathrm{C}\right)$. Similar trend was observed in Jamalpur and Rajbari location. The longest vegetative phase was observed in Rajbari and the shortest vegetative phase was observed in Joydebpur due to comparatively lower temperature prevailed in Rajbari than other two locations during cropping period. On the other hand, the longest reproductive phase ( 33 days with 512 GDD) was observed in 10 November sowing due to prevailing lower mean temperature $\left(20.5^{\circ} \mathrm{C}\right)$ and the shortest reproductive phase $(21$ days with lowest GDD 420) was observed in 20December sowing due to prevailing maximum mean air temperature $\left(25.0^{\circ} \mathrm{C}\right)$ followed by 10 December sowing $(24$ days with 438 GDD due to prevailing mean air temperature $23.2^{\circ} \mathrm{C}$ ) in Joydebpur shown (Table 1 and Table 2). Similar trend was observed in Jamalpur and Rajbari locations. As a result, 20 December sowing took the minimum duration (95 days at Joydebpur, 96 days at Jamalpur and 98 days at Rajbari to reach physiological maturity with minimum GDD (1530, 1528 and 1525 at Joydebpur, Jamalpur and Rajbari, respectively) and 30 November sowing took the maximum duration to reach physiological maturity with maximum GDD followed by 20 November sowing in all the locations (Table 3). It might be due to comparatively higher temperature prevailed at the earlier and later sowing than 20-30 November sowing. Longer duration (105 days at Joydebpur, 106 days at Jamalpur and 109 days at Rajbari, respectively) due to prevailing lower temperature $\left(20.4^{\circ} \mathrm{C}, 20.3^{\circ} \mathrm{C}\right.$ and $19.1^{\circ} \mathrm{C}$ at Joydebpur, Jamalpur and Rajbari, respectively) with higher GDD (1639, 1638 and 1640 at Joydebpur, Jamalpur and Rajbari, respectively) produced the higher grain yield. The result of the present experiment was also supported by (Ahmed $e t$ $a l ., 2015)$. They reported that higher GDD produced the higher grain yield in maize production. 
Table 1. Required duration, mean temperature and GDD for vegetative phase as affected by sowing date during rabi of 2018-2019 (Joydebpur, Jamalpur and Rajbari)

\begin{tabular}{lccccccccc}
\hline \multirow{2}{*}{$\begin{array}{l}\text { Sowing } \\
\text { date }\end{array}$} & \multicolumn{8}{c}{ Vegetative phase (Seeding to Anthesis) } \\
\cline { 2 - 10 } & \multicolumn{7}{c}{ Duration (days) } & \multicolumn{7}{c}{ Mean air temperature $\left.{ }^{\circ} \mathbf{C}\right)$} & \multicolumn{3}{c}{ Growing degree day (GDD) } \\
\cline { 2 - 10 } & Joy. & Jam. & Raj. & Joy. & Jam. & Raj. & Joy. & Jam. & Raj. \\
\hline 10 Nov. & 69 & 69 & 71 & 20.6 & 20.5 & 19.2 & 1074 & 1067 & 1061 \\
20 Nov. & 72 & 73 & 76 & 20.1 & 20.0 & 18.7 & 1089 & 1097 & 1100 \\
30 Nov. & 75 & 76 & 77 & 19.9 & 19.6 & 18.4 & 1115 & 1113 & 1097 \\
10 Dec. & 74 & 75 & 76 & 19.9 & 19.7 & 18.5 & 1101 & 1105 & 1099 \\
20 Dec. & 74 & 75 & 76 & 20.0 & 19.8 & 18.8 & 1110 & 1112 & 1108 \\
\hline
\end{tabular}

Table 2. Required duration, mean temperature and GDD for reproductive phase as affected by sowing date during rabi of 2018-2019 (Joydebpur, Jamalpur and Rajbari)

\begin{tabular}{lccccccccc}
\hline \multirow{2}{*}{$\begin{array}{l}\text { Sowing } \\
\text { date }\end{array}$} & \multicolumn{8}{c}{ Reproductive phase (Anthesis to Physiological maturity) } \\
\cline { 2 - 9 } & \multicolumn{7}{c}{ Duration (days) } & \multicolumn{3}{c}{ Mean Temperature $\left({ }^{\circ} \mathbf{C}\right)$} & Growing degree day (GDD) \\
\cline { 2 - 9 } & Joy. & Jam. & Raj. & Joy. & Jam. & Raj. & Joy. & Jam. & Raj. \\
\hline 10 Nov. & 33 & 33 & 35 & 20.5 & 20.5 & 19.4 & 512 & 513 & 514 \\
20 Nov. & 32 & 32 & 33 & 21.0 & 20.9 & 20.4 & 514 & 510 & 508 \\
30 Nov. & 30 & 30 & 32 & 22.5 & 22.5 & 22.0 & 524 & 525 & 543 \\
10 Dec. & 24 & 25 & 26 & 23.2 & 23.0 & 22.6 & 438 & 451 & 458 \\
20 Dec. & 21 & 21 & 22 & 25.0 & 24.8 & 24.0 & 420 & 416 & 417 \\
\hline
\end{tabular}

Table 3. Required duration, mean temperature and GDD for physiological maturity as affected by sowing date during rabi of 2018-2019 (Joydebpur, Jamalpur and Rajbari)

\begin{tabular}{lccccccccc}
\hline \multirow{2}{*}{$\begin{array}{l}\text { Sowing } \\
\text { date }\end{array}$} & \multicolumn{8}{c}{ Crop duration (Seeding to Physiological maturity) } \\
& \cline { 2 - 10 } & \multicolumn{7}{c}{ Duration (days) } & \multicolumn{7}{c}{ Mean Temperature $\left({ }^{\circ} \mathbf{C}\right)$} & \multicolumn{3}{c}{ Growing degree day (GDD) } \\
\cline { 2 - 10 } & Joy. & Jam. & Raj. & Joy. & Jam. & Raj. & Joy. & Jam. & Raj. \\
\hline 10 Nov. & 102 & 102 & 106 & 20.5 & 20.5 & 19.3 & 1586 & 1580 & 1575 \\
20 Nov. & 104 & 105 & 109 & 20.4 & 20.3 & 19.2 & 1603 & 1607 & 1608 \\
30 Nov. & 105 & 106 & 109 & 20.4 & 20.3 & 19.1 & 1639 & 1638 & 1640 \\
10 Dec. & 98 & 100 & 102 & 20.7 & 20.6 & 19.6 & 1539 & 1556 & 1557 \\
20 Dec. & 95 & 96 & 98 & 21.1 & 20.9 & 20.0 & 1530 & 1528 & 1525 \\
\hline
\end{tabular}

\section{Yield and yield attributes}

Yield and yield contributing characters of wheat in all locations have been presented in Table 4, Table 5 and Table 6. The maximum spikes $\mathrm{m}^{-2}$ was observed in 30 November sowing and the lowest in 20 December sowing in all locations. The maximum spike length was obtained from 30 November sowing which was identical with 20 November and 10 November sowing and the minimum spike length from 20 December sowing followed by 10 December sowing in all locations. Higher grains spike ${ }^{-1}$ (47.2, 48.9 and 49.9 at, respectively) was observed in 30November sowing which was statistically similar with 20 November and 10 November sowing and the lowest (38.2, 40.6 and 41.0 at Joydebpur, Jamalpur and Rajbari, respectively) was observed in 20 December sowing followed by 10 December sowing in all locations. The highest 1000 -grain weight $(50.73 \mathrm{~g}, 52.35 \mathrm{~g}$ and $52.59 \mathrm{~g}$ respectively) was observed in 30 November sowing which was statistically similar with 20 November and 10 November sowing and the lowest $(42.27,42.48$ and $46.11 \mathrm{~g}$ at Joydebpur, Jamalpur and Rajbari, respectively) was observed in 20 December sowing followed by 10 December sowing in all locations. The maximum grain yield $\left(4.90^{1}, 4.99\right.$ and $5.03 \mathrm{t} \mathrm{ha}^{-1}$, respectively) was observed in 30 November sowing which was statistically similar with 20 November sowing due to cumulative effect of better yield components and the lowest grain yield (3.15, 3.29 and $3.39 \mathrm{t} \mathrm{ha}^{-1}$ at Joydebpur, Jamalpur and Rajbari, respectively) was observed in 20 December sowing followed by 10 December sowing due to cumulative effect of poor yield components in all locations. It was observed that 30 November sowing received lower 
temperature during cropping period that caused longer crop growth duration and ultimately produced higher TDM and translocation of higher TDM to grain. It might be 30 November sowing probably received favorable environment mainly optimum temperature resulting better vegetative growth of the plants which ultimately led to the better flowering, grain filling and finally increased grain yield. On the other hand, the lowest grain yield was observed in 20 December sowing. It was founded that 20 December sowing crop received cool temperature at early growth stage which produced profuse tillering and higher temperature at reproductive phase that hastened maturity and reduced TDM production and translocation of less dry matter to the reproductive organ (grain). Grain yield of wheat was found higher at Rajbari than other two locations. It might be due to maximum and minimum temperature prevailed during wheat growing period at Rajbari was lower than other two locations (Fig. $5)$.

Table 4. Plant height, spikes $\mathrm{m}^{-2}$ and spike length (cm) of wheat as affected by sowing date during rabi of 2018-2019 (Joydebpur, Jamalpur and Rajbari)

\begin{tabular}{lccccccccc}
\hline Sowing date & \multicolumn{3}{c}{$\begin{array}{c}\text { Plant height } \\
(\mathrm{cm})\end{array}$} & \multicolumn{3}{c}{$\begin{array}{c}\text { Spikes } \mathrm{m}^{-2} \\
(\text { no. })\end{array}$} & \multicolumn{3}{c}{$\begin{array}{c}\text { Spike length } \\
(\mathrm{cm})\end{array}$} \\
\cline { 2 - 10 } & Joy. & Jam. & Raj. & Joy. & Jam. & Raj. & Joy. & Jam. & Raj. \\
\hline 10 November & 99.7 & 95.6 & 97.9 & 393 & 438 & 416 & 9.9 & 9.7 & 9.9 \\
20 November & 97.2 & 94.7 & 95.0 & 413 & 443 & 428 & 10.1 & 9.9 & 10.1 \\
30 November & 96.9 & 89.8 & 90.8 & 415 & 448 & 432 & 10.1 & 10.1 & 10.3 \\
10 December & 95.8 & 85.3 & 89.4 & 328 & 342 & 335 & 8.8 & 8.9 & 8.7 \\
20 December & 89.5 & 82.6 & 86.4 & 315 & 335 & 325 & 9.0 & 9.1 & 9.2 \\
\hline LSD $(0.05)$ & NS & NS & NS & 51.56 & 66.17 & 52.69 & 0.52 & 0.57 & 0.82 \\
CV (\%) & 5.31 & 5.99 & 7.30 & 7.34 & 8.76 & 7.23 & 2.87 & 3.19 & 4.52 \\
\hline
\end{tabular}

Table 5. Grains spike ${ }^{-1}, 1000$-grain wt. and grain yield of wheat as affected by sowing date during rabi of 2018-2019 (Joydebpur, Jamalpur and Rajbari)

\begin{tabular}{|c|c|c|c|c|c|c|c|c|c|c|c|c|}
\hline \multirow[t]{2}{*}{ Sowing date } & \multicolumn{3}{|c|}{ Grains spike $^{-1}$ (no.) } & \multicolumn{3}{|c|}{ 1000-grain wt. (g) } & \multicolumn{3}{|c|}{ Grain yield $\left(\mathrm{t} \mathrm{ha}^{-1}\right)$} & \multicolumn{3}{|c|}{$\begin{array}{l}\text { Yield reduction over } \\
30 \text { Nov. sowing (\%) }\end{array}$} \\
\hline & Joy. & Jam. & Raj. & Joy. & Jam. & Raj. & Joy. & Jam. & Raj. & Joy. & Jam. & Raj. \\
\hline $10 \mathrm{Nov}$ & 44.5 & 45.1 & 47.8 & 47.40 & 48.91 & 50.18 & 3.97 & 4.07 & 4.17 & 18. & 18.4 & 17.1 \\
\hline 20 Nor & 46.7 & 47.4 & 49.5 & 49.07 & 51.09 & 51.38 & 4.77 & 4.80 & 95 & 2.7 & 3.8 & 1.6 \\
\hline $30 \mathrm{No}$ & 47.2 & 48.9 & 49.9 & 50.73 & 52.35 & 52.59 & 4.90 & 4.99 & 5.03 & - & - & - \\
\hline 10 Dece & 38.5 & 42.0 & 42.8 & 42.93 & 42.97 & 46.44 & 3.29 & 3.34 & 3.41 & 32. & 33.1 & 32.2 \\
\hline 20 December & 38.2 & 40.6 & 41.0 & 42.27 & 42.48 & 46.11 & 3.15 & 3.29 & 3.39 & 35.7 & 34.1 & 32.6 \\
\hline $\operatorname{LSD}_{(0 .}$ & 4.85 & 4.06 & 4.32 & 4.60 & 4.24 & 3.81 & 0.33 & 0.48 & 0.75 & . & - & - \\
\hline CV (\%) & 5.99 & 4.78 & 4.97 & 5.26 & 4.74 & 4.11 & 4.35 & 6.19 & 9.48 & - & - & - \\
\hline
\end{tabular}

Yield reduction was observed (3-36, 4-34 and 2-33\% at Joydebpur, Jamalpur and Rajbari, respectively) for earlier and later sowing over 30 November sowing. The result of the present study was also supported by Kamrozzaman et al. (2016). The variations in yield and yield contributing characters of wheat due to sowing date were also observed by Gul et al. (2012) and Uddin et al. (2015). Similar trend was also observed in straw yield, biological yield and harvest index (HI). 
Table 6. Straw yield, biological yield and harvest index of wheat as affected by sowing date during rabi of 2018-2019 (Joydebpur, Jamalpur and Rajbari)

\begin{tabular}{lccccccccc}
\hline \multirow{2}{*}{ Sowing date } & \multicolumn{3}{c}{ Straw yield $\left(\mathbf{t ~ h a}^{-\mathbf{1}}\right)$} & \multicolumn{3}{c}{ Biological yield $\left(\mathbf{t} \mathbf{h a}^{\mathbf{- 1}}\right)$} & \multicolumn{3}{c}{ HI $(\boldsymbol{\%})$} \\
\cline { 2 - 10 } & Joy. & Jam. & Raj. & Joy. & Jam. & Raj. & Joy. & Jam. & Raj. \\
\hline 10 November & 4.63 & 4.700 & 4.07 & 8.600 & 8.767 & 8.98 & 46.12 & 46.40 & 46.38 \\
20 November & 5.35 & 5.347 & 5.08 & 10.13 & 10.15 & 10.53 & 47.13 & 47.31 & 47.02 \\
30 November & 5.48 & 5.543 & 5.36 & 10.38 & 10.53 & 10.68 & 47.24 & 47.32 & 47.03 \\
10 December & 3.89 & 3.977 & 3.34 & 7.180 & 7.32 & 7.42 & 45.82 & 45.67 & 45.89 \\
20 December & 3.82 & 4.120 & 3.29 & 6.963 & 7.41 & 7.42 & 45.18 & 44.41 & 45.62 \\
\hline LSD $(0.05)$ & 0.31 & 0.39 & 1.07 & 0.63 & 0.80 & 1.49 & - & - & - \\
CV (\%) & 3.55 & 4.45 & 13.44 & 3.86 & 4.79 & 8.79 & - & - & - \\
\hline
\end{tabular}

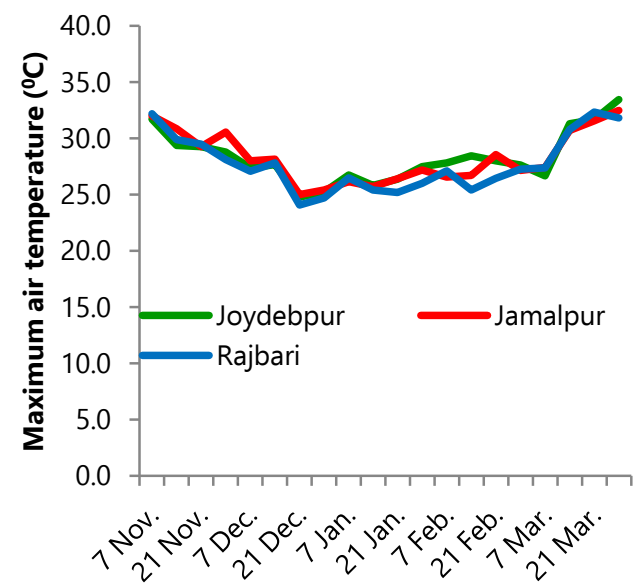

Wheat growing period

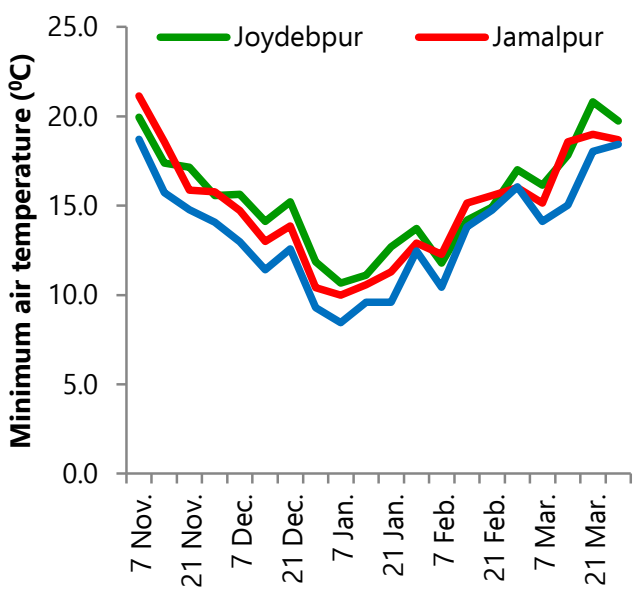

Wheat growing period

Fig. 5.Weekly maximum and minimum air temperature of Joydebpur, Jamalpur and Rajbari during crop growing period in 2018-2019

\section{Relationship between grain yield and air temperature}

There was a negative linear relationship between grain yield $\left(\mathrm{t} \mathrm{ha}^{-1}\right)$ of wheat and air temperature of three locations has been shown in Fig. 6. At Joydebpur, the regression line $(y=-2.381 x+53.11$, $\mathrm{R}^{2}=0.82$ ) indicated the regression of co-efficient was 2.381 stated that grain yield of wheat decreased at the rate of $2.381 \mathrm{t} \mathrm{ha}^{-1}$ for per unit increase of air temperature $\left({ }^{\circ} \mathrm{C}\right)$. The co- efficient of determination $\left(\mathrm{R}^{2}=0.82\right)$ value indicated that air temperature had effect at $82 \%$ on grain yield of wheat. Similar expression was made by the regression line $\left(y=-2.894 x+63.49, R^{2}=0.825\right)$ and $(y=-1.951 x+42.12$, $\mathrm{R}^{2}=0.83$ ) at Jamalpur and Rajbari, respectively. So, increasing temperature decreases the grain yield of wheat. Similar results also have been described by Mian et al. (2016).Temperature co-efficient (average of three locations) of wheat was estimated at $2.41 \mathrm{t} \mathrm{ha}^{-1}\left(1.95-2.89 \mathrm{t} \mathrm{ha}^{-1}\right)$ indicated grain yield reduced @ $2.41 \mathrm{t} \mathrm{ha}^{-1}$ per $1^{\circ} \mathrm{C}$ increased of air temperature. Effect of temperature on the grain yield of wheat was estimated at $81-84 \%$.Similar results also have been described by Asseng et al. (2010). They surprisingly, observed variations in average growing-season temperatures of $\pm 2{ }^{\circ} \mathrm{C}$ in the main wheat growing regions of Australia can cause reductions in grain production of up to $50 \%$. 

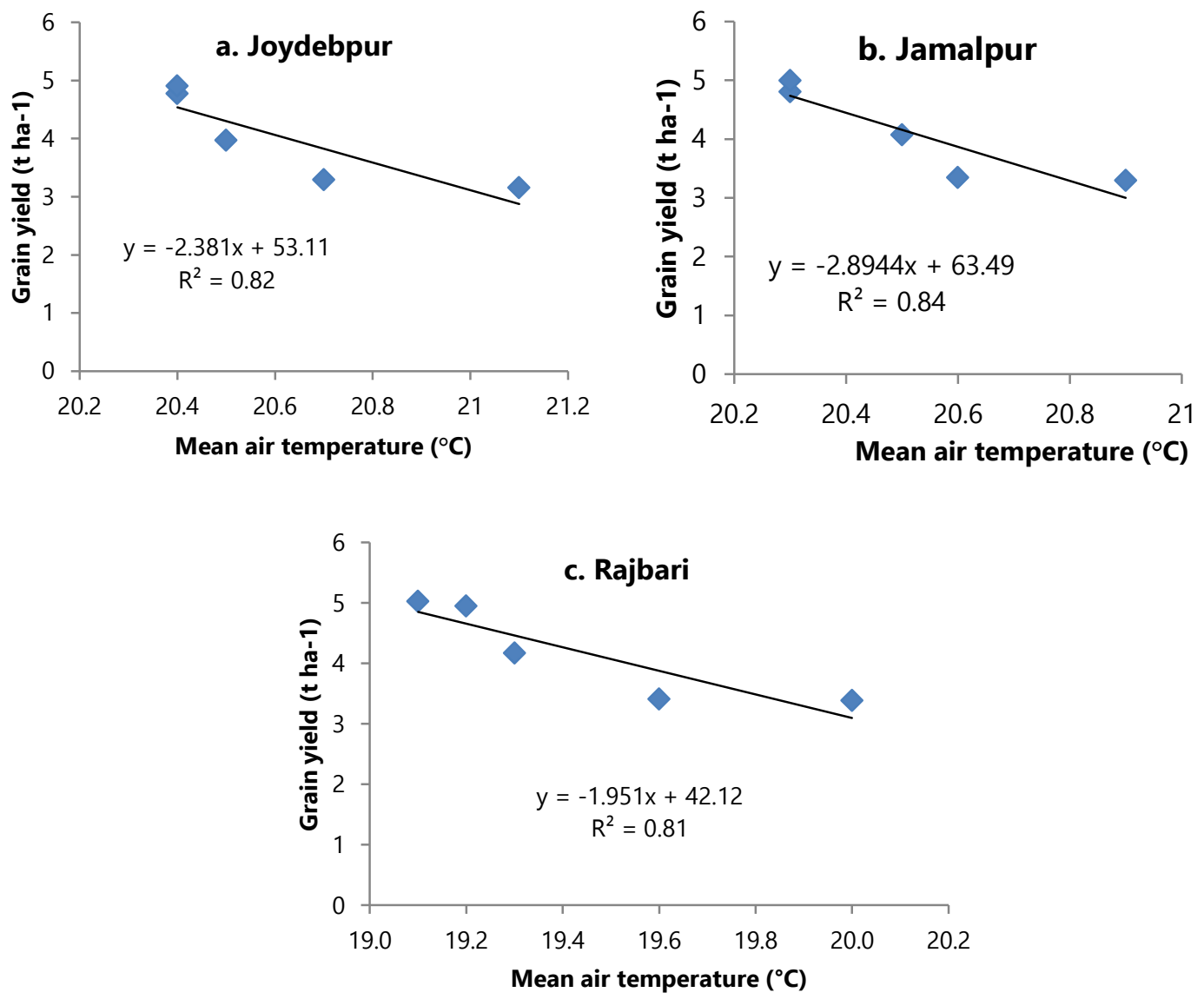

Fig. 6.Functional relationship between mean air temperature and grain yield of wheat

\section{Conclusion}

The results revealed that physiological maturity as well as crop duration of wheat was reduced by the influence of higher temperature. Sowing during 20 November to 30 November would be the optimum sowing date for wheat in relation to air temperature, and early or late sown caused about $2-36 \%$ yield reduction over 30 November sowing. Temperature co-efficient of wheat was estimated at $2.41 \mathrm{t} \mathrm{ha}^{-1}$ (1.95-2.89 $\left.\mathrm{t} \mathrm{ha}^{-1}\right)$ indicated grain yield reduced @ $2.41 \mathrm{t} \mathrm{ha}^{-1}$ per $1{ }^{\circ} \mathrm{C}$ increased of air temperature and effect of temperature on the grain yield of wheat was estimated at $81-84 \%$.

\section{References}

Ahmad, N., N.H. Shaha, M. Habibullah and F.U. Khan. 2005. Effects of different seed rates, sowing dates and weed control on grain yield of wheat. Pakistan J. Weed Sci. Res. 11(3/4): 109-113.

Ahmed, F., M.S.A. Khan and M.H. Rahman. 2015. Developmental stages, growth indices and yield of hybrid maize cultivars as affected by growing seasons. Annual research report 2014-2015, Plant Physiol. Div., Bangladesh Agril. Res. Inst. 24p.

Asseng, S., F. Ian and T.C. Nail. 2010. The impact of temperature variability on wheat yields. Global Change Biol. 17(2): $997-1012$. 
BARC. 2012. FRG (Fertilizer Recommendation Guide), Bangladesh Agricultural Research Council, Bangladesh. Farmgate, New Airport Road, Dhaka. p.44

Coasta, R., N. Pinheiro, A.S. Ameida, C. Gomes, J. Coutinho, J. Coco, A. Costa, and B. Nacas. 2013. Effect of sowing date and seeding ratio on bread wheat yield and test weight under Mediterranean conditions. Emirates J. Food and Agric. 25: 951-961.

Gul, H., B. Saeed, A.Z. Khan, U. Latif, K. Ali, J. Rehman and S. Rehman. 2012. Yield and yield contributing traits of wheat cultivars in relation with planting dates and nitrogen fertilization. ARPN J. Agril. Biol. Sci. 7(6): 386- 395.

Kamrozzaman M.M, M.A.H. Khan, S. Ahmed and N. Sultana. 2016. Growth and yield of wheat at different dates of sowing under charland ecosystem of Bangladesh. J. Bangladesh Agril. Univ. 14(2): 147154.

Khan, M.S.A. and M.A. Aziz. 2015. Impact of sowing date induced temperature and management practices on development events and yield of mustard. Bangladesh Agron. J. 18(2): 45-52.

Mian, M.A.K., M.R. Islam, J. Hossain and M.A. Aziz. 2016. Grain growth of wheat under prevailing air temperature. Bangladesh Agron. J. 19(2): 79-85.

Uddin, R., M.S. Islam, M.J. Ullah, P.K. Hore and S.K. Paul. 2015. Grain growth and yield of wheat as influenced by variety and sowing date. Bangladesh Agron. J. 18(2): 97-104. 